\title{
Radio and the Road: Infrastructure, Mobility, and Political Change in the Beginnings of Radio Rurale de Kayes (1980-early 2000s) ${ }^{*}$
}

\author{
Aïssatou Mbodj-Pouye \\ Centre National de la Recherche Scientifique (CNRS), Institut des Mondes Africains, \\ Aubervilliers
}

\begin{abstract}
Mali's first non-state radio went on air during the authoritarian rule of Moussa Traoré in 1988, challenging the common narrative that ties political and media liberalization together.

Negotiations were conducted by Italian NGOs at a time when such organizations had become key political actors in Sahelian countries. The implementation of Radio Rurale de Kayes was part of a wider infrastructural project that notably included a road. This historical account follows the metaphorical and literal association between the radio and the road in order to reflect on mobility and its constraints. Tracing the radio's trajectory from space-making to community-building, it shows how the station managed to sustain itself thanks to its position within an emerging network of associations led by return migrants and because of how it fitted into local infrastructures of mobility, thus calling for a stronger attention to the relation between radio, the audiences it convenes, and space.
\end{abstract}

\section{Key Words}

Mali, West Africa, media, technology, development, transport, migration.

Texte remis à l'éditeur, pour la version publiée, voir

Journal of African History, Cambridge University Press (CUP), 2021, 62 (1), pp.125-149. $\langle 10.1017 / \mathrm{S} 0021853721000086\rangle$

\footnotetext{
${ }^{*}$ Research for this article was supported by a Marie Skłodowska-Curie fellowship at Point Sud, Bamako and IMAF, Aubervilliers, funded by the European Union's Horizon 2020 research and innovation program. My warmest thanks go to Radio Rurale de Kayes's director Darrar Ben Azour Maguiraga and to all the station's staff. I offer this paper as a tribute to the memory of Samba Sylla and Demba Traoré, two invaluable interlocutors who passed away in 2019. I thank Amadou Koné and Mamady Sissoko for their help in the archives of the Gouvernorat and Mamadou Diarra for transcribing some of the interviews. I am grateful to JeanPhilippe Dedieu for his careful reading of drafts of this paper, to Dominic Horsfall for precise language-editing work, and to the editors and anonymous reviewers of The Journal of African History for insightful suggestions. Author's email: mbodj@cnrs.fr.
} 
'That was the idea behind the rural radio station. The Italians said: we will build a road, but the fastest way for people to meet, that's radio.' ${ }^{1}$

'Even if the road is damaged, radio still allows people to communicate. That's how the idea of the station came about.' 2

While recounting the circumstances of the founding of Radio Rurale de Kayes (RRK) in 1988, former radio workers often told stories about roads. The radio station and the road came together as part of an Italian-funded development program for the Kayes region in Western Mali following the droughts that had affected the Sahel in the 1970s and 1980s. Setting up a radio station required the installation of new and visible infrastructures, such as wires and antennas, as well as the construction of a segment of road. Besides empirical connections between the construction of roads and the implementation of a radio station, accounts often conflated the station with the road as distinct but related means of communication - as two modes of connecting people and rendering them mobile.

In the vein of Brian Larkin's study of radio in colonial Nigeria, albeit for a different period, this paper builds on the infrastructural turn in the social sciences to explore the relationship between radio, space, and the audiences it convened. ${ }^{3}$ A growing literature emphasizes the political work of infrastructure and technology in colonial and postcolonial African contexts. ${ }^{4}$ Discussing the renewed interest in technology among historians of Africa,

\footnotetext{
${ }^{1}$ Interview with Abdoulaye Dramé, Kayes, 18 Jan. 2018. Interviews were conducted mostly in French and occasionally in Bamanan. All translations are mine.

2 Interview with N'Golo Coulibaly, Bamako, 5 Feb. 2018.

${ }^{3}$ B. Larkin, Signal and Noise: Media, Infrastructure, and Urban Culture in Nigeria (Durham, NC, 2008). On the infrastructural turn, see B. Larkin, 'The politics and poetics of infrastructure', Annual Review of Anthropology, 42:1 (2013), 327-434.

${ }^{4}$ S. Quinn 'Infrastructure, ethnicity, and political mobilization in Namibia, 1946-87', The Journal of African History, 61:1 (2020), 45-66; A. von Schnitzler, 'Traveling technologies: infrastructure, ethical regimes, and the materiality of politics in South Africa', Cultural Anthropology 28:4 (2013), 670-93.
} 
Keith Breckenridge and Gabrielle Hecht have highlighted the potential of multidisciplinary approaches, building on developments in anthropology and archeology and contributing to global discussions in science and technology studies. ${ }^{5}$ Pushing further their argument about technology and place as two possible starting points for research, my study is anchored in a place, but discusses the space-making potential of the radio. The connection between radio technology and mobility has been powerfully explored by Debra Spitulnik in her study of the portability of radio sets in Zambia. ${ }^{6}$ However, attention to infrastructure prompts us to reflect on this intersection on a different scale by considering the radio station as part and parcel of an infrastructural assemblage comprising not only roads but also vehicles that allow radio producers to circulate in the area and listeners to drop by in person with messages, not to mention telephones, faxes, and letters. ${ }^{7}$

Conceived as a way of supplementing a development project formulated in the early 1980s, the radio station was initially thought of as both a form of infrastructure and an accompaniment to infrastructural development. This project grew out of post-drought interventions that, as Gregory Mann has argued, made possible the increased involvement of

\footnotetext{
${ }^{5}$ D. Serlin, 'Confronting African histories of technology: a conversation with Keith Breckenridge and Gabrielle Hecht', Radical History Review, 127 (2017), 87-102.

${ }^{6} \mathrm{D}$. Spitulnik, 'Mobile machines and fluid audiences: rethinking reception through Zambian radio culture', in F. Ginsburg, L. Abu-Lughod, and B. Larkin (eds), Media Worlds: Anthropology on New Terrain (Berkeley, 2002), 337-54. Richard Vokes and Katrien Pype have suggestively invited scholars to explore the relationship between information and communication technologies and spatial categories, see R. Vokes and K. Pype, 'Chronotopes of media in sub-Saharan Africa', Ethnos 83:2 (2018), 2.

${ }^{7}$ Though focused on the radio, this paper not only draws on stories about roads, but also considers transport infrastructures (absent or present, derelict or maintained) as key parts of the historical context. Roads and motor transportation are also an emergent topic in African history. See, for example, L. Freed, 'Networks of (colonial) power: roads in French Central Africa after World War I', History and Technology 26:3 (2010), 203-23; J. Hart, Ghana on the Go: African Mobility in the Age of Motor Transportation (Bloomington, IN, 2016).
} 
NGOs in the Sahel in place of 'state-centered developmentalism'. ${ }^{8}$ The project combined an interventionist approach aimed at enhancing living conditions in one region with an emphasis on the participation of rural masses through the medium of radio — participation being the watchword of rural development projects of the time. ${ }^{9}$ Because radio had until then been a state monopoly and scarcely covered this peripheral region, and in a context where other means of communications such as phones were poorly developed, building an information and communication network with a reach of $150 \mathrm{~km}$ served to consolidate this territory: hence, the idea of radio making space and its audience as active beneficiaries of a development project. Two decades later and separate from any infrastructural plan, RRK connected groups and individuals across a region no longer thought of as one space of intervention. Following diasporic — mainly Soninke — networks, it contributed instead to the formation of a new radiophonic community alongside other FM stations. It is this trajectory, from space-making to community-building, that I trace here. ${ }^{10}$

This study covers two decades, from the inception of a radio project in 1983 to the central presence of RRK in the regional media landscape of the early 2000s. This timeframe encompasses the pivotal moment of the liberalization of African airwaves, often characterized by the conjunction of the spread of FM technology and the political and legal

\footnotetext{
${ }^{8}$ G. Mann, From Empires to NGOs in the West African Sahel: The Road to Nongovernmentality (Cambridge, 2014), 172.

${ }^{9}$ J.-P. Chauveau, 'Participation paysanne et populisme bureaucratique: essai d'histoire et de sociologie de la culture du développement', in J.-P. Jacob and P. Lavigne Delville (eds.), Les associations paysannes en Afrique: Organisation et dynamiques (Paris, 1994), 25-60.

${ }^{10}$ On audiences in Africa, see the seminal article by K. Barber, 'Preliminary notes on audiences in Africa', Africa, 67: 3 (1997), 347-62. On the potential of radio technology to create publics at distinct scales, including transnational, see L. Gunner, D. Ligaga, and D. Moyo (eds.), Radio in Africa: Publics, Cultures, Communities (Johannesburg, 2011).
} 
changes introduced in the wake of the political transitions of the early 1990 s. $^{11}$ This association between the liberalization of the airwaves and 'democratization' has been challenged by studies calling for more nuanced accounts of popular media beyond normative assumptions drawn from democratization theory. ${ }^{12}$ While this critique focuses on the postliberalization moment, my intention is to nuance this general periodization by looking at an early instance of the development of FM radio which blurs such a periodization.

As demonstrated by a growing scholarship on radio in Africa, this media was crucial to many nation-building projects. ${ }^{13}$ In Mali, under the first president Modibo Keïta, radio was used in a didactic way to foster the sense of a national community across regional differences. ${ }^{14}$ After Moussa Traoré overthrew Modibo Keïta in a coup in 1968 and established military rule, national radio was even more tightly controlled. ${ }^{15}$ Both leaders used the radio, by far the most widespread media, as a key political and cultural instrument. ${ }^{16}$ In 1988 RRK became the first and only breach in the regime's monopoly over the airwaves as a result of the adroit positioning of its initiators. Less than three years later, in March 1991,

\footnotetext{
${ }^{11}$ R. Fardon and G. Furniss (eds.), African Broadcast Cultures: Radio in Transition (Oxford, 2000).

${ }^{12}$ H. Wasserman (ed.), Popular Media, Democracy and Development in Africa (London, 2011); F. BrissetFoucault, Talkative Polity: Radio, Domination, and Citizenship in Uganda (Athens, OH, 2019).

${ }^{13}$ For an overview, see H. Englund, 'Radio as a political medium in Africa', The Oxford Encyclopedia of African Politics, (https://doi.org/10.1093/acrefore/9780190228637.013.814), 2019. Recent monographs address the intricate relationships between radio and the state in African history, such as Liz Gunner's demonstration of how Zulu-language radio managed to escape the narrow space the apartheid ideologues assigned it and Marissa Moorman's analysis of the unstable role of radio technology in colonial and postcolonial Angola; see L. Gunner, Radio Soundings: South Africa and the Black Modern (Cambridge, 2019); and M. Moorman, Powerful Frequencies: Radio, State Power, and the Cold War in Angola, 1931-2002 (Athens, OH, 2019).

${ }^{14}$ C. H. Cutter, 'Nation-building in Mali: art, radio, and leadership in a pre-literate society' (unpublished $\mathrm{PhD}$ thesis, University of California, Los Angeles, 1971).

${ }^{15}$ The de facto monopoly on telecommunications was inscribed in a law promulgated on 18 Jan. 1983. R. Lake, 'Mali: le pluralisme radiophonique', in Institut Panos and Union des journalistes de l'Afrique de l'Ouest (eds.), Le pluralisme radiophonique en Afrique de l'Ouest (Paris, 1993), 4.

${ }^{16}$ D. Schulz, Perpetuating the Politics of Praise: Jeli Singers, Radios, and Political Mediation in Mali (Köln, 2001); M. Diawara, L'empire du verbe et l'éloquence du silence: Vers une anthropologie du discours dans les groupes dits dominés au Sahel (Köln, 2003).
} 
after months of violently repressed contestation from students and other segments of the population, a military coup opened a period of interim rule. During the following months, a national conference was organized, leading to the organization of the first multiparty elections, the adoption of a new constitution in January 1992, and, that same month, the adoption of a legal framework authorizing private radios. While in most accounts, RRK's 'exception' receives at best a passing mention, this paper reveals the previously undocumented connections between the station in Kayes and the later development of free radio stations in Bamako in 1991-2. ${ }^{17}$ It further brings to an historical account an attention to audiences, sociotechnical aspects, and social dynamics around radio stations that characterizes studies on the ulterior decades when local FM stations burgeoned in Mali as elsewhere in Africa. ${ }^{18}$ Besides filling a gap in the historiography of media in Mali, inserting the history of RRK within the political, social, and cultural history of this country is also a call to fully integrate the studies of rural and regional radio stations within the broader scholarship on radio and media in Africa, beyond the normative angle that dominates existing accounts often written by (former) practitioners. ${ }^{19}$

This study of RRK relies on semi-structured interviews conducted with men and women of various backgrounds and occupations, some still active at the station and others

\footnotetext{
${ }^{17}$ RRK is generally treated as an epiphenomenon compared to the development of other stations after 1991, see M. Myers, 'The promotion of democracy at the grass-roots: the example of radio in Mali', Democratization, 5:2 (1998), 200-16. See, however, the short account in Lake, 'Mali', and the mention of RRK as 'the prototype for local radio stations in Mali' in C. Tower, 'Radio ways: society, locality, and FM technology in Koutiala, Mali' (unpublished PhD thesis, Northwestern University, 2008), 120.

${ }^{18}$ D. Schulz, "In pursuit of publicity": talk radio and the imagination of a moral public in urban Mali', Africa Spectrum, 34:2 (1999), 161-85; C. Tower, 'Radio ways'.

${ }^{19}$ Such as J. P. Ilboudo, 'Prospects for rural radio in Africa: strategies to relate audience research to the participatory production of radio programmes', in Fardon and Furniss, African Broadcast Cultures, 42-71.
} 
who left at various stages. ${ }^{20}$ Staying at the station's hostel during my fieldtrips to Kayes allowed me to spend time with the present team in their offices and studios as well as under the station's veranda - itself a lively discussion space. One of the station's offices is dedicated to 'archives and documentation': its records provide a unique view into the negotiations that led up to its launch, the recruitment of the first collaborators and their work practices, and the daily management of the station. Listeners' letters offer further insights into the audience. ${ }^{21}$

\section{Setting things in motion: Development as désenclavement}

Located on the Senegal River, the axis of colonial progress, Kayes was the first capital of

French Sudan before this moved to Bamako in $1908 .^{22}$ Its role as the main stop on the DakarBamako railroad — with the junction with Bamako completed in 1904 and with Thiès, Senegal, in 1923 - made it an important regional hub. However, in 1960 the separate independences of Mali and Senegal after the break-up of the short-lived Mali Federation created tensions between the two countries, and Mali closed its border. ${ }^{23}$ Although railroad traffic was reinitiated in 1963, the region remained peripheral, with each newly created

\footnotetext{
${ }^{20}$ I have conducted 31 interviews in Kayes, Bamako, Kati, and Paris. Based in Bamako from 2017 to 2019, I regularly travelled to Kayes for research trips. On the occasion of RRK's thirtieth anniversary, I collaborated with the radio team on an illustrated publication, 'Une histoire de la Radio Rurale de Kayes: récits, photos \& documents' (Bamako, 2019).

${ }^{21}$ In addition to the archival material kept at Radio Rurale de Kayes (hereafter ARRK), I have also explored public collections, predominantly the archives of the Gouvernorat de la région de Kayes (hereafter AGRK).

${ }^{22}$ R. N’Diaye Keita, Kayes et Le Haut Sénégal, Volume I (Bamako, 1972), 85-6.

23 'Both nations, but particularly Mali, experienced severe economic dislocation. The western region of Mali, centered on Kayes, was devastated by the closure of the railroad and the border with Senegal.' A. F. Clark, 'From military dictatorship to democracy: the democratization process in Mali', Journal of Third World Studies, 12:1 (1995), 209.
} 
country gravitating towards its capital and other axes of communication and trade. ${ }^{24}$ In 1987 the administrative region of Kayes, which covered slightly more than 120,000 square kilometers, numbered approximately one million out of the country's 7.7 million inhabitants. ${ }^{25}$ No asphalt road connected the city of Kayes to the capital Bamako (Fig. 1). ${ }^{26}$

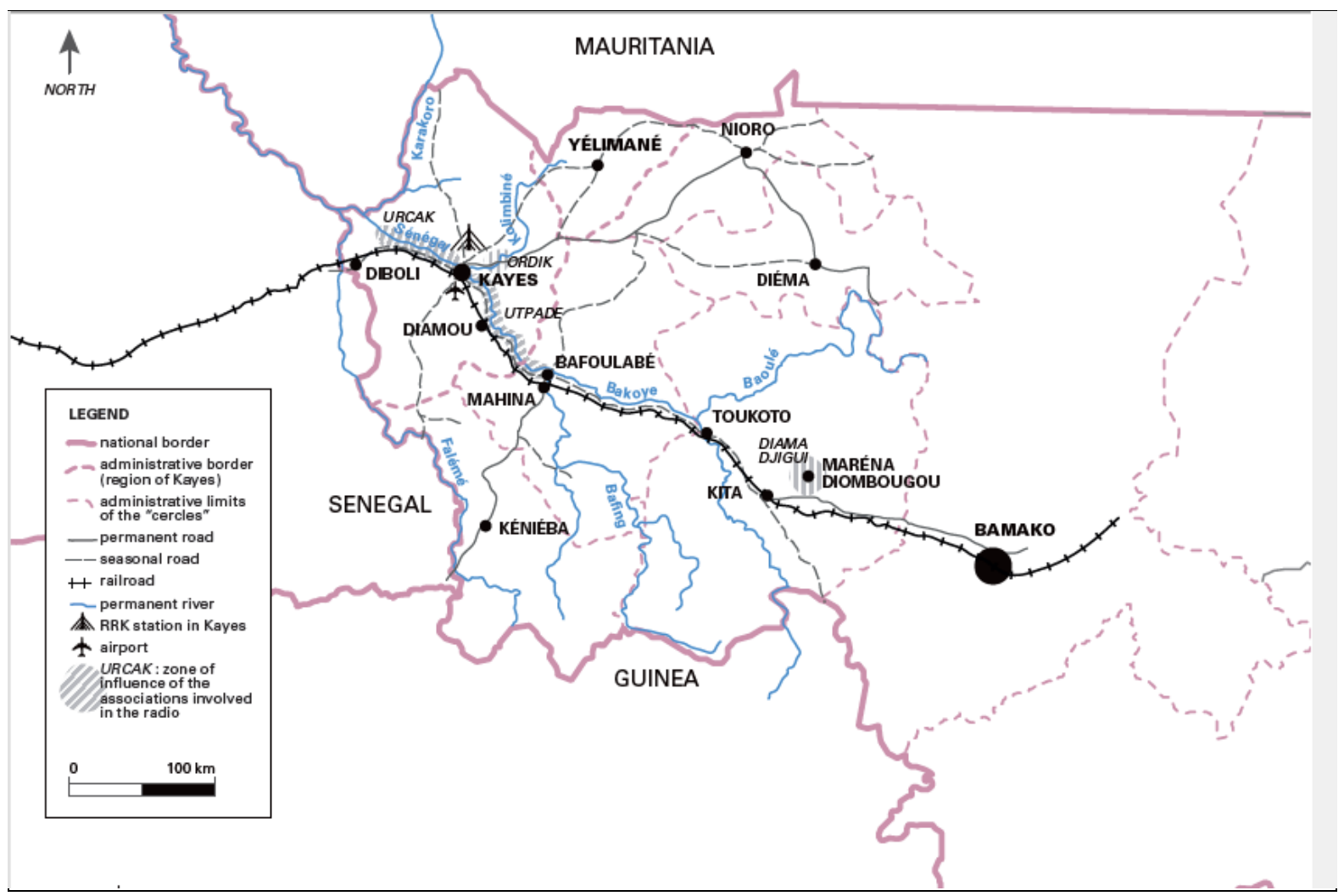

Fig. 1. The Kayes Region in 1988. Map by Célio Paillard.

${ }^{24}$ N'Diaye Keïta, Kayes I, 171.

${ }^{25}$ Figures from S. Keïta and F. O. Konaté 'Le Mali et sa population', in V. Hertrich and S. Keïta (eds.), Questions de population au Mali (Bamako, 2003), 48.

${ }^{26}$ J. Lombard, 'Kayes, ville ouverte', Autrepart, 47:3 (2008), 93. 
This apparent isolation went together with sustained practices of mobility that had long histories. Due to its location at the junction of trans-Saharan trade and commercial routes towards the coasts, the area had been the cradle of jula trade networks spanning West Africa. ${ }^{27}$ As François Manchuelle has argued, longue durée practices of periodic trade migration paved the way for an involvement of the Soninke into new mobility patterns in the colonial era: towards Senegambia for the cultivation of peanuts and as sailors in service of the French along the Senegal River. ${ }^{28}$ At the end of the nineteenth century, the Soninke diaspora extended further into Central Africa in the context of French expansion and to other destinations in West Africa, notably coastal cities such as Dakar. ${ }^{29}$ As sailors and industrial workers, they later went to Europe. Beyond these most visible processes of male migration driven by commercial and labor opportunities, the region also experienced high levels of internal and outward mobility of women and families in the aftermath of the official abolition of slavery in $1905 .^{30}$

Initially encouraged by colonial authorities attempting to direct manpower where needed, labor migration was subsequently opposed in the late colonial period. ${ }^{31}$ Under Modibo Keïta, the Malian state set up tight policies in order to control the movements of its

\footnotetext{
${ }^{27}$ The term jula refers to Muslim long-distance traders who established their networks between the eleventh and fifteenth centuries as an 'extension of the trans-Saharan trade network beyond the port towns of the sahel, into the savannas and toward the Atlantic'. D. Wright, 'Darbo Jula: the role of a Mandinka Jula clan in the longdistance trade of the Gambia River and its hinterland', African Economic History, 3 (1977), 35. Their origins are generally traced to Soninke clans, see M. Perinbam 'The Julas in Western Sudanese history: long-distance traders and developers of resources', in B. K. Swartz and R. E. Dumett (eds.), West African Culture Dynamics: Archeological and Historical Perspectives (The Hague, 1980), 456.

${ }^{28}$ F. Manchuelle, Willing Migrants: Soninke Labor Diasporas, 1848-1960 (Athens, OH, 1997).

${ }^{29}$ Manchuelle, Willing Migrants; B. Whitehouse, Migrants and Strangers in an African City. Exile, Dignity, Belonging (Bloomington, IN, 2012).

${ }^{30}$ M. Rodet, Les migrantes ignorées du Haut-Sénégal: 1900-1946 (Paris, 2009).

${ }^{31}$ Manchuelle, Willing Migrants, ch. 6.
} 
population and labelled migrants 'traitors' ${ }^{32}$ In Kayes these attempts were more or less easily circumvented thanks to the proximity of the Senegalese border, which migrants could cross on foot before subsequently securing Senegalese rather than Malian identification papers. ${ }^{33}$ After the 1968 coup, Moussa Traoré's regime developed a more liberal policy towards migrants but maintained some level of control on rural exodus. ${ }^{34}$ Migrants from Kayes, notably those in France, where they accounted for the bulk of sub-Saharan immigrants were still subjected to administrative harassment, notably by custom officers, on the occasion of their visits. A 1972 letter from the director of customs in Bamako testifies to their hardship:

Every year, some Malian workers take advantage of their annual leave to visit their family. They bring many items with them: clothes, radio receivers, and tape recorders, not for sale, but for distribution between kin and friends in the village. They are cautious to duly perform the custom formalities at the airport in Bamako. But these precautions do not prevent a second search to which they are subjected upon arrival in the railway station in Kayes. ${ }^{35}$

While indicating the crucial role of migrants in the circulation of radio sets, this document demonstrates how mobility depended not only on infrastructure but also on administrative

\footnotetext{
${ }^{32}$ D. Gary-Tounkara, 'Quand les migrants demandent la route, Modibo Keïta rétorque: "Retournez à la terre!”: les "Baragnini" et la désertion du "chantier national" (1958-1968)', Mande Studies 5 (2003), 49-64.

${ }^{33}$ Archives Nationales du Mali, Bamako (ANM) fonds documentaire 609, M. Niambélé, 'Rapport de mission: immigration des travailleurs maliens en France', Dec. 1963, 9. I thank Greg Mann for sharing his copy of this document.

${ }^{34}$ D. Gary-Tounkara, 'Encadrement et contrôle des migrants par le régime militaire au Mali (1968-1991)', in S. Dufoix, et al. (eds), Loin des yeux, près du cœur (Paris, 2010), 147-62

${ }^{35}$ ANM CMLN/UDPM 284, letter from General Director of Customs, Bamako to T. Bakayoko, Director of the Security Services, 16 Jan. 1972.
} 
and political constraints. However, a key argument for the NGOs promoting the project of the RRK was the perceived isolation of the region formulated mainly in geographical terms.

The rural radio station emerged from a wider program of Italian cooperation under the auspices of the Fondo aiuti italiani (FAI), which was created in 1985 to respond to emergency situations in sub-Saharan Africa, notably in the post-drought Sahel. ${ }^{36}$ Italy benefitted from an increased level of involvement of NGOs in West Africa, which made it possible for nonFrench actors to set foot in the francophone Sahelian states. ${ }^{37}$ Through its contributions to the Comité permanent inter-États de lutte contre la sécheresse dans le Sahel (CILSS), it positioned itself as an actor in the field of development aid. ${ }^{38}$ Italian aid mainly took the form of 'integrated rural development projects'.39

The Italian program promoted development through two main projects: the reconstruction of the road toward Senegal and the renovation of Kayes's hospital. These infrastructural works were carried out by the Italian engineering firm AIC Progetti under the supervision of the NGO Terra Nuova. ${ }^{40}$ The rebuilding of the road that followed the railroad west from the city of Kayes to the border town of Diboli was intended to open up communication links with Senegal and serve localities along the Senegal River, where

\footnotetext{
${ }^{36}$ On the FAI, see P. Bollini and M. R. Reich, 'The Italian fight against world hunger: a critical analysis of Italian aid for development in the 1980s', Social Science \& Medicine, 39:5 (1994), 611.

${ }^{37}$ Mann, Empires to NGOs.

${ }^{38}$ On Italian aid to the Sahel, see E. Caputo, 'Iniziativa italiana di cooperazione con i paesi del CILSS: Una valutazione preliminare a tre anni dall'inizio', Africa: Rivista trimestrale di studi e documentazione dell'Istituto italiano per l'Africa e l'Oriente, 40:3 (1985), 349-70.

${ }^{39}$ On another such project, see B. Rossi, 'The Keita Project: an anthropological study of international development discourses and practices in Niger' (unpublished PhD thesis, London School of Economics and Political Science, 2002). The Keita Project also included a rural radio station but Rossi's study does not detail this aspect.

40 Terra Nuova was created in 1968 and oriented towards Latin America before setting foot in Africa in 1975, and in Mali in 1982, see Terra Nuova, Centro per la Solidarietà e la Cooperazione tra i popoli, (http://www.terranuova.org/terra-nuova-en/our-story), 2021.
} 
irrigation projects led by former migrants returned from France had developed during the previous decade. This segment of the Nationale 1 road had existed since colonial times but had been reduced to a mere track. The choice of this axis was not straightforward. A preliminary version of the Italian project had targeted the road from Kayes to Yélimané, one of the region's secondary cities as well as a center of emigration. ${ }^{41}$ As for the road to Diboli, other plans had been made to rebuild it: funding was expected from the German Federal Republic in 1980 and from USAID in $1983 .{ }^{42}$ These vacillations attest to the volatility of projects that often did not materialize, as well as the ability of Malian actors to manage the plurality of donors and redirect aid according to their own needs.

During preliminary studies in 1983 , these infrastructure projects were envisioned as part of a wider program that also included an element of training that would rely on a rural radio station. ${ }^{43}$ The involvement of the NGO GAO-Cooperazione Internazionale (hereafter GAO) in 1985 helped to make radio a key component of the project rather than merely a useful side note. GAO was a newly established NGO set up by academics from the sociology and political science departments at the University of Calabria, among them Ada Cavazzani, the NGO president, and Giordano Sivini, both of whom previously worked in Ethiopia. ${ }^{44}$ Communications expertise came from experiments that had been conducted in rural Italy at

\footnotetext{
${ }^{41}$ ARRK, 'Programme de développement rural intégré de la région de Kayes-Nord. Rapport de la mission conjointe FAO/Gouvernement Italien', May 1983.

${ }^{42}$ On the German project, see Centre des Archives diplomatiques du ministère des Affaires étrangères, La Courneuve, 20881 K484, 'Opérations des périmètres irrigués de la région de Kayes. Mission d'examen de la situation', Oct. 1980, 10. On the American project, see USAID, Projet de développement intégré USAID/OMVS (Dakar, 1983), 64.

${ }^{43}$ ARRK, 'Programme de développement rural intégré', 1983.

${ }^{44}$ G. Sivini, Resistance to Modernization in Africa: Journey among Peasants and Nomads (New Brunswick, NJ, 2011). On the contribution by academics to the definition of Italian cooperation, see Rossi, 'The Keita Project', $111 \mathrm{n} 45$.
} 
the University of Calabria's Center for Radio-Television by Felice Spingola, who became head of the radio project in Kayes.

Under the impulse of GAO, an ambitious program of 'animation and training' was set up. It was based on fieldwork carried out in the 402 villages of the cercles of Kayes and Yélimané. ${ }^{45}$ The ambition was to 'integrate infrastructure and productive interventions promoted by Italian cooperation with a series of measures intended to foster the participation of populations in the management of development projects and to publicize the interventions within the territory'. ${ }^{46}$ This would mainly take shape through the establishment of a rural radio station.

The idea behind the radio and infrastructure program, despite distinct actors and aims, was that the region was suffering primarily from enclavement, a French word denoting isolation and remoteness used to describe landlocked areas — which in turn made désenclavement, or opening up, the main motto of the two programs ${ }^{47}$ Fily Keïta, the first Malian director, recalled:

What we gathered from the survey conducted in local villages was the need to provide the region of Kayes with . . . because there are many isolated areas [zones enclavées].

\footnotetext{
${ }^{45}$ ARRK, survey by FAI, AIC Progetti (Rome), and BECIS (Bamako), 'Etude pour le développement des cercles de Kayes et de Yélimané: enquête socio-économique', 1987. This survey comprised 188 items and covered a vast array of themes, such as the history of the locality, its demographics, the state of its infrastructure, and an assessment of its 'needs' in term of development and of the involvement of its emigrants. ${ }^{46}$ ARRK 'Protocole de mise en application du Programme d'animation et de formation pour le développement rural dans la région de Kayes', 7 Feb. 1987.

${ }^{47}$ Presented as two distinct layers in the program and implemented by separate NGOs, the infrastructure project and the training project were put in place by a group who shared some acquaintances. Thus, when the team working on the radio project required construction works, they called AIC Progetti to build the road from the station to the antenna.
} 
But even more back then: during the rainy season, you couldn't go where you wanted, some villages were cut off for four, six months, that was dreadful, and the only means to connect people was a tool like radio, we needed it. ${ }^{48}$

The opening words of an article by one of the radio project's Italian volunteers provided an even more dramatic evocation of the situation:

Only the tiny ribbon of the one-way railroad, often interrupted by natural or mechanical accidents, and the telephone line, even more fragile, link the region of Kayes with the rest of Mali or neighboring Senegal. There is no road network, and the few tracks that do exist are often impassable or devastated by soil erosion. ${ }^{49}$

This view from above probably reflects the Italians' frequent use of air travel to go from Bamako to Kayes - as observed by Malian members of the team. ${ }^{50}$ This depiction ties together infrastructures of mobility (the railway) and communication (the telephone), emphasizing the breakable nature of these two lines. The new pair of the road and the radio would provide more reliable transportation and communication systems.

The radio station was further endowed with the potential to contribute to development, understood as a form of social engineering that would render populations

\footnotetext{
${ }^{48}$ Interview with Fily Keïta, Bamako, 6 Dec. 2017.

${ }^{49}$ D. Barazzetti, 'Des émissions à l'écoute des femmes'. Supplement to the French edition of Cooperazione, 14:85 (1989), 26. The journal was published by the Italian ministry of foreign affairs.

50 '[The Italians] flew over the region in a small plane ... Hence, they decided to build communication routes, roads.' Interview with N'Golo Coulibaly. No regular air service existed between Bamako and Kayes, but the Italians used planes chartered by private firms in Kayes for their expatriates to move around.
} 
receptive to new forms of organization. Cavazzani laid out the ambitions of the radio project in the following terms:

Using radio, we intend to support the ongoing processes of transformation occurring at the level of social structures, reinforcing the most dynamic elements and helping to eliminate obstacles originating from the rigidity of traditional hierarchies. ${ }^{51}$

The notion of the 'most dynamic elements' pointed notably to women and migrants. Furthermore, radio would encourage the circulation of news between one locality and another and between migrants and their home villages. This in turn was seen as providing a new way to share experiences, and in particular development success stories. This is a leitmotiv of the interviews that I conducted, expressed through an oft-repeated aphorism on the absence of communication between villages, as in this explanation given by Felice Spingola:

Every migrant sought to bring development to his village. But they did not even know each other, even between villages located a few kilometers apart. They replicated things they had heard of without engaging in a deeper understanding of their environment. All of them dreamed of building a clinic, a pharmacy, a mosque, a garden, a cooperative store, etc. ... While talking with them in France and in their villages, we thought: that's not possible! There was clearly a lack of communication

\footnotetext{
${ }^{51}$ A. Cavazzani, 'Une radio rurale à Kayes'. Supplement to the French edition of Cooperazione, 14:85 (1989), 28.
} 
between them. We had to find a way to make them the protagonists of social change. Hence the choice of radio, not in French, or any outside languages, so that things would not be remote-controlled. ${ }^{52}$

Thus, the initiators of the radio project emphasized participation from the ground up. They believed that all that was missing were the channels of communication; they were uninformed or oblivious to the vernacular dynamics of communication, where silence and omission were central, and to the social context, which was characterized by emulation as much as by cooperation between localities.

Expected to transform social relations within villages and across a region, the radio thus valued mobility metaphorically by targeting, in Cavazanni's words, 'the most dynamic elements' of society. ${ }^{53}$ 'Like all infrastructures, radio was about making things mobile and placing them in circulation. But as with other infrastructures, that space of circulation was not neutral but encoded a relation between the state and its subjects. ${ }^{, 54}$ This quotation by Larkin applies fully to RRK insofar as the ambitions driving the project were to encourage social change. However, the space that Larkin delineates between 'the state and its subjects' needs to be complicated by the presence of nonstate transnational actors such as the NGOs, whose relations with the Malian state were determined by a political context to which I now turn.

\footnotetext{
${ }^{52}$ Interview with Felice Spingola, Bamako, 6 Feb. 2018. Broadcasts were in Soninke, Khassonke, Bamanan, and Fulfulde - languages that the Italians did not understand. Though occasionally they would ask that a broadcast on a sensitive topic be transcribed and translated, this was not ordinary practice; this meant that, from day to day, the Malian team had a great level of autonomy.

${ }^{53}$ Cavazzani, 'Radio rurale', 28.

${ }^{54}$ Larkin, Signal and Noise, 49.
} 


\section{'Radio as a vehicle': A depoliticizing strategy for nonstate actors}

The radio station went on air in August 1988 using FM technology for the first time in Mali, allowing Kayesians to access radio with local contents and with much better sound quality than what they could hear on short waves from the national radio or foreign stations. The opening was negotiated with the authorities under the military government of Moussa Traoré at a time when the regime, born out of the 1968 coup, had turned to single-party rule following the creation of the Union démocratique du peuple malien (UDPM) in 1979. This authoritarian regime exerted tight control on the media. Still, the opening of the station attests to the diversity of positions within the regime. The account that follows is sensitive to the multiple interpretations - and retrospective postures — of the actors involved in its creation. While fitting in with the view of the late 1980 s as a period of relative political liberalization, it also supplements existing studies that focus solely on Bamako and on the timid emergence of plurality in the press after the start of the periodical Jamana in $1983 .{ }^{55}$

Negotiations before RRK's launch mainly involved two ministries: the Ministry of Territorial Administration and Grassroots Development, since the station formed part of the wider development program introduced above, and the Ministry of Information and Telecommunications. Acceptance of the station is often explained by its inclusion in the wider project, a 'package' that the Malian government could not rightly refuse. ${ }^{56}$ In this context, the emphasis placed on the station's instrumental dimension as a mere conduit for information is presented as a discursive strategy, as Spingola makes clear:

\footnotetext{
${ }^{55}$ P. J. Imperato and G. H. Imperato, Historical Dictionary of Mali (4th edn, Lanham, MD, 2008), 181; T. Perret, 'Médias et démocratie au Mali', Politique africaine, 97:1 (2005), 20.

56 'The Italians offered the Malian government a bunch of presents, saying: here is an emergency project for the region. Since the program included RRK, [the Malians] said: no problem, we'll take the project.' Interview with Fily Keïta.
} 
The whole battle with the minister of territorial administration was to have them think of the station as a means of désenclavement, not political, but actually very, very political, because information is political. To see the station as a plow, a tractor, a donkey, a pirogue ... something that allows people to get to the village quicker, to connect with their relatives, emigrants. ${ }^{57}$

Spingola presents the association of the radio station with the road as a trick to depoliticize a project that in fact had a political intent. These negotiations benefitted from a favorable context, as Colonel Issa Ongoïba, minister of territorial administration at the time, 'favored the legal recognition of associations', another token of political opening. ${ }^{58}$

While it is difficult to measure the degree of reluctance, support, or indifference to the radio project, its perimeter of action was delineated by strict principles and rules: broadcasting in local languages, being centered on development issues, targeting rural audiences, and refraining from political topics — all this was stipulated by the Ministry of Information through the Radiodiffusion Télévision du Mali (RTM) ${ }^{59}$ The proposal came at a time when the notion of 'rural radio' had currency within the RTM. Launched in 1967, a rural radio service (division radio rurale) operated within Radio-Mali. After the 1968 coup and the

\footnotetext{
${ }^{57}$ Interview with Felice Spingola.

${ }^{58} \mathrm{~S}$. Nédelec, 'Jeunesses, sociétés et État au Mali au XXe siècle' (unpublished PhD thesis, Université Paris Diderot-Paris 7, 1994), 454. While touring the region in October 1988, Ongoïba visited RRK, a visit publicized in L'Essor (Bamako), 3 Nov. 1988.

${ }^{59}$ RTM was established in 1983 in replacement of Radio-Mali and was renamed Office de Radiodiffusion Télévision du Mali (ORTM) in 1992, when it gained a more autonomous legal status. In the first elaborations of the FAI program, rural radio was presented as supporting 'the aims of the Five-Year Plan in terms of the regionalization of Radio Mali', before GAO came in and insisted on the independence of the project from the RTM. ARRK ‘Programme de coopération technique', 1983.
} 
subsequent reorganization of agricultural development on a regional basis, funding for the rural radio service came through regional Opérations de développement rural (ODR), with broadcasts designed to explain technical information to the public. However, this funding mechanism stopped in 1981 . Thus, when the RRK project emerged, the rural radio service within the RTM had lost momentum. It broadcast a weekly educational program for peasants in national languages, Poyi kan poyi (a formulaic phrase borrowed from Bamanan oral poetry and used in literacy classes to introduce poems), which was criticized for being top-down in its conception. As with other broadcasts in national languages, this program had a strong bias in favor of Bamanan, the lingua franca across most of the country, although far from understood in all regions. This situation explains why some RTM administrators eagerly engaged in the RRK experiment as a way to revitalize their activities within the RTM, in a context when rural radio initiatives were being developed in West Africa. ${ }^{60}$

The result of the negotiation was the RTM's limited but effective involvement in the newly created station, initially in the form of RTM staff: three technicians were provisionally assigned to Kayes to operate the radio. Furthermore, several qualified RTM managers helped train the new team, notably the head of the rural radio service, N'Golo Coulibaly, who was later brought in by GAO as a consultant and researcher for $\mathrm{RRK}^{61}$ Later, the RTM requested

\footnotetext{
${ }^{60}$ Notably in Burkina Faso at the Centre Interafricain d'Etudes en Radio Rurale de Ouagadougou, created in 1979. A. J. Tudesq, L'Afrique parle, l'Afrique écoute: Les radios en Afrique subsaharienne (Paris, 2002), 84. On the exchanges between Burkina Faso's rural radio and RRK, see A. Cavazzani and N. Coulibaly, La Radio rurale au Sahel (1991), a film produced by GAO, RTM, and the University of Calabria (http://www.gaong.org/index.php?option=com_content\&view=article\&id=54:19\&catid=17\&Itemid=138). ${ }^{61}$ ARRK, N. Coulibaly, 'Communication et développement rural: la "radio rurale" au Mali: perspectives de décentralisation et participation'. Quaderni di GAO, Collana Ricerche 13, GAO-Cooperazione internazionale, 1996.
} 
that RRK retransmit the daily news program in French, as well as Poyi kan poyi. ${ }^{62}$ This demand attests to the RTM's awareness of the limited audience it had previously had when relying on shortwave broadcasts and the interest it could gain from the new FM diffusion.

The RTM's involvement in RRK has been understood in a number of different ways, and there are conflicting interpretations of the arrangement between the RTM and the Italian non-governmental organization GAO. Since the RTM was in the process of developing regional centers, some thought that the RRK would later merge with the already existing but ill-equipped regional center. ${ }^{63}$ Hence, Salif Sidibé, a qualified technician assigned by RTM to join the RRK staff, explained : 'I was sent by the [RTM] so that, after two years, we could inherit some properly maintained equipment' ${ }^{64}$ This view was clearly stated in April 1989 when GAO requested an extension to the project: 'To the Ministry of Information's understanding, RRK was meant to be an embryo of the regional RTM station in Kayes. ${ }^{95}$ The Italians objected to such a view, which had not been laid down in the signed agreement. As we will see, drastic political changes in 1991 and the involvement of migrants' associations in the station's management ultimately made it possible for RRK to remain independent from the RTM.

Beyond the arrangements made in Bamako, the NGO also had to interact with authorities in Kayes. In this respect, an important contribution was made by the Gouvernorat,

\footnotetext{
${ }^{62}$ The daily news program was retransmitted more or less regularly (repeated letters from the RTM demanding that it be done suggest a lack of commitment by RRK).

${ }^{63}$ The governor of the Kayes region had asked for reinforcements for the regional RTM center ahead of RRK's launch. See AGRK 2W1 285, letter from the Governor to the Minister of Information, 9 June 1988.

${ }^{64}$ Interview with Salif Sidibé, Bamako, 31 Jan. 2018.

${ }^{65}$ ARRK, minutes of a meeting on the extension of the project at the Ministry of Information, Bamako, 5 April 1989.
} 
which provided a decaying colonial building next to Kayes's airport that once housed air force officers. Reputedly haunted, it was situated in an isolated area that people feared to visit after dusk. ${ }^{66}$ The Gouvernorat also engaged in surveillance of the project: on opening day, the governor warned the team that he would 'keep an eye on them', while the UDPM's local section 'invited' them to one of their meetings so that they could present the project. ${ }^{67}$

'Radio Rurale de Kayes' — this seemingly plain denomination was in keeping with the station's declared function as a medium dedicated to rural audiences focusing on development issues. However, in hindsight RRK also became known as the first radio libre in Mali (Fig. 2).

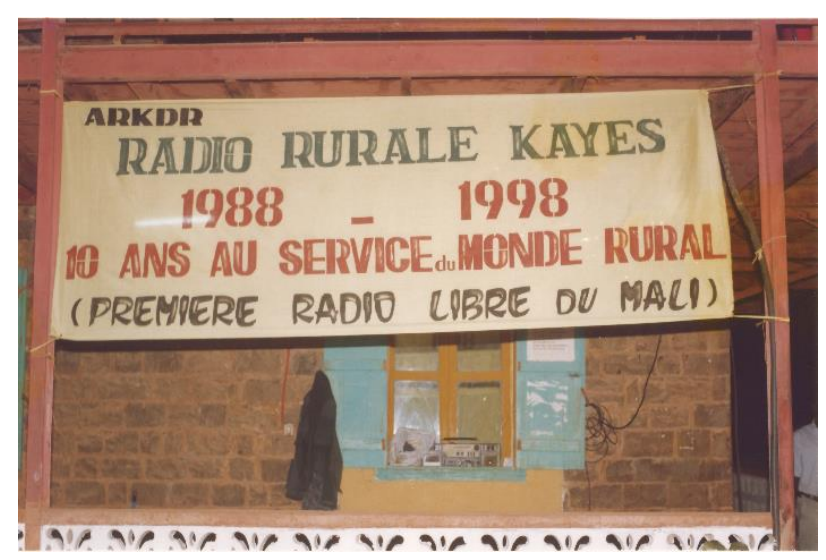

Fig. 2. Picture of a banner at the entrance to Radio Rurale de Kayes on the occasion of its tenth anniversary, 1998. Photograph courtesy of Radio Rurale de Kayes.

Semantics aside, this raises the most disputed point about the station's status in the retrospective accounts that I collected. Some actors decisively tied the RRK experiment to

\footnotetext{
${ }^{66}$ Interview with Demba Traoré, Kayes, 4 Oct. 2018.

${ }^{67}$ Interviews with Ibrahima Traoré, Kayes, 8 Nov. 2017 and Georges Diawara, Bamako, 29 Jan. 2018.
} 
later developments that led to the liberalization of the airwaves three years later in Bamako. Abdoulaye Dramé, who was approached by GAO members at an early stage of the project while he was still a migrant in France, thus interpreted the creation of the RRK as a continuation of his political ideals:

ABDOULAYE DRAMÉ: We had a hut here for meetings. Because there was a revolutionary idea behind it all, because the University of Calabria, it was like Paris VIII, you see, full of revolutionaries. ${ }^{68}$ There were also documents, because we said that we needed somewhere to put a Roneo [a kind of duplicating machine] for leaflets and stuff, and also to develop photographs. That was the initial idea, in the hut where we met [pointing to a now vacant space behind the station].

AUTHOR: You said they were revolutionaries, but how did they reconcile this with the Traoré regime?

ABDOULAYE DRAMÉ: We had our tricks. ... When we were in France, there were free radio stations there, so we called it free radio [radio libre] as well. The Italians said, 'No, we'll call it 'rural radio', are you mad, Dramé: free radio?! We’ll say rural radio.' But most free radio stations in Mali took their inspiration from us. ${ }^{69}$

\footnotetext{
${ }^{68}$ Université Paris VIII, established at Vincennes in 1971, had grown out of the experimental Centre universitaire de Vincennes, which in turn was founded in the aftermath of May 1968. A leftist stronghold, it was moved to another Parisian suburb, Saint-Denis, in 1980.

${ }^{69}$ Interview with Abdoulaye Dramé. Dramé had notably responsibilities in a workers' trade-union in France.
} 
Indeed, some RRK actors — including Keïta, by then the station's director — participated in the collective organization of the first free radio stations. ${ }^{70}$ However, most narratives emphasize instead the team's circumspection and the fact that, content-wise, RRK did not exceed its limits.

AUTHOR: Some call RRK the first free radio station in Mali ...

N'Golo Coulibaly: Well, free of state monopoly, yes, but it remained local, because it doesn't cover the whole region, and even if it did, it would still be local. But 'free'? It was clear from the outset that it was a rural radio station, and that most of its programs had to deal with development. ${ }^{71}$

N'Golo Coulibaly established a difference between independence from the state, which RRK achieved, and the status of a 'free radio station' offering alternative political views from state media, an ambition that, in his view and in contrast to Abdoulaye Dramé's statement, was not part of RRK's program. These tensions echo the differences within the team in terms of sociological background and political orientation, as further evidenced by Georges Diawara's stance. Recruited for his status as a high school social sciences teacher in Kayes, having studied at a Catholic university in France, he stated that he had joined the station in 1988 because of his commitment to development.

\footnotetext{
${ }^{70}$ Lake acknowledges the material contribution by Italian members of GAO and Terra Nuova to the implementation of Radio Bamakan (the first non-state radio in Bamako, which started to broadcast in September 1991) but does not mention the involvement of Malian radio actors from Kayes. See Lake, 'Mali', 23.

${ }^{71}$ Interview with N'Golo Coulibaly.
} 
AUTHOR: Among the former migrants coming back from France, some had been activists as workers in France. Was that part of a collective identity within RRK?

GEORGES DiAWARA: Well, this spirit, some people tried to develop it, but I don't consider it fundamental. Plus, some of those who'd come back to Mali more than twenty years earlier kept on thinking as immigrants: that's not serious!

AUTHOR: You mean they had revolutionary ideas that did not stand the test of time?

GEORGES DIAWARA: What revolutionary ideas? A few had been influenced in France. But it can't be said that the station was built on the basis of this dynamic! No! It was based on the idea of developing a region, and on the assessment of the difficulties in communicating. Context counted for more than doctrine. That's why I mentioned the road: the road unlocked the region [la route a désenclavé]. What's so revolutionary about that? Without the road as an opening tool, some villages would have continued to stagnate. ${ }^{72}$

For Diawara, equating the radio station with a road is a way to describe it as a mere conduit for information. Thus, there are contrasting uses of this metaphor: some were strategic, by actors willing to intervene politically, while others adhered to an apolitical view of development. ${ }^{73}$

\footnotetext{
${ }^{72}$ Interview with Georges Diawara.

${ }^{73}$ I focus here on the station workers, for whom the road denoted progress. Although not a context for such tragic memories as those studied by Adeline Masquelier regarding the Nigerien N1, roads in the region could still be regarded suspiciously. See A. Masquelier, 'Road mythographies: space, mobility, and the historical imagination in postcolonial Niger', American Ethnologist, 29:4 (2002), 829-56. For instance, on special
} 
The discursive nexus between the road, radio, and occasionally other instruments for mobility could lend itself to an analysis in terms of a 'poetics of infrastructures' that emphasizes technological and infrastructural 'enchantments' ${ }^{74}$ Such a reading is powerful, as it helps understand the developmentalist imaginary of many of RRK's promoters, both foreign and local. Here, I suggest a different path by moving beyond metaphors to explore the way in which mobility, on different scales, was integral to the success of the radio project. I contend that the continuous joint evocation of the road and the radio station attests to a deeper affinity between mobility and radio. I thus turn toward an examination of the kind of mobility that the station actually depended on and further induced. First, I will demonstrate how the station worked and managed to attract local audiences precisely because people were already on the move.

\section{The role of migrants in the emergence and survival of the radio station}

Migrants and return migrants (former migrants in France who had come back as part of development projects) were central in the conception and implementation of RRK. It was in France that Italians from GAO first reached out to Malian migrants in order to initiate research and development projects in Mali. Among their first interlocutors were leaders of Diama Djigui ('Hope of the People' in Soninke and Bamanan), the region's first transnational association. ${ }^{75}$ Based in Maréna (60 km east of Kayes) and including three other villages

\footnotetext{
occasions, such as the arrival of a bride, villagers from Sobokou would move onto the side of the road to perform a ritual before crossing one of the bridges on the Kayes-Diboli axis. Author's fieldnotes, March 2019. ${ }^{74}$ Larkin, 'Politics and poetics'; P. Harvey and H. Knox, 'The enchantments of infrastructure', Mobilities, 7:4 (2012), 521-36.

${ }^{75}$ Diama Djigui was founded in France in 1981 and in Mali in 1982 by villagers and migrants returning from France. AGRK, 'Emigration: Maliens expatriés', a declaration of creation of the association Diama Djigui to the
} 
(Mokoyafara, Sabouciré, and Madinacouta), the association's main project was the opening of a clinic. From the mid-1980s, the radio project was discussed in France and in Italy, where the GAO team invited one of the migrants to present documentary films shot in France on their working and living conditions and return aspirations. ${ }^{76}$ The influence of Diama Djigui members was such that the station's location was originally envisioned in Maréna before Kayes was ultimately selected as a more central site. ${ }^{77}$

This dynamic of return was indeed strong at the time RRK was created. From the mid1970s onwards, collective and individual return projects flourished, from France in particular. At a time of economic crisis, the idea of (former) migrants as developers crystallized at the junction of French policies and migrants' projects. ${ }^{78}$ Ibrahima Traoré recalled how he joined RRK: 'In 1988, I came back with a development project for the nine villages in my area. At that time, this coincided with the arrival of the rural radio station. ${ }^{79}$

In fact, several of the station's key actors came from this social milieu of return migrants. Among them were members of the first collective project of returnees from France, established in 1977 at Somankidi-Coura (the new Somankidi, in Bamanan, from the name of the adjacent village), west of Kayes.$^{80}$ Ladji Niangané, one of the 14 founding members of

Ministry of Interior, 7 April 1982. See also C. Daum, Les associations de maliens en France: Migrations, développement et citoyenneté (Paris, 1998).

${ }^{76}$ Among the films produced by the University of Calabria and directed by F. Spingola were Emigrati Maliani in Francia (1985), 'Diama Djigui', Speranza di un Popolo (1986), and Ritorno al FLEUVE (1987). Titles quoted in ARRK, 'Programma logistico d'urgenza nella $I^{\circ}$ regione della Repubblica del Mali, relazione di sintesi', 31 July 1986.

${ }^{77}$ Interview with Abdoulaye Dramé.

78 J.-P. Dedieu, 'The rise of the migration-development nexus in francophone sub-Saharan Africa, 1960-2010', African Studies Review, 61:1 (2018), 83-108.

${ }^{79}$ Interview with Ibrahima Traoré.

${ }^{80}$ On Somankidi-Coura, see S. Soumaré, Après l'émigration le retour à la terre: L'exemple de SomankidiKoura (Bamako, 2001). 
Somankidi-Coura, was the station's first Malian manager. ${ }^{81}$ Born on the Senegalese side of the border, Niangané had connections with regional Soninke organizations. He introduced Demba Traoré, from Bakel, Senegal and then living in Dakar, to the team in Kayes. The local contributors trained to make recordings in the villages for the station also included several return migrants, and the geography of this network maps onto the collective projects led by returnees along the Senegal River. ${ }^{82}$

Likewise, in the wider infrastructure program, the final choice of the Kayes-Diboli axis for the road project resulted from the involvement of these return migrants, who by 1983 were organized into the Union régionale des cooperatives agricoles de Kayes (URCAK). URCAK acted as the main interlocutor of the Fondo aiuti italiani (FAI), instead of the regional branch of the ODR, the Opération Vallée du Sénégal-Térékolé-Magui. In so doing, URCAK took advantage of GAO's preference for associations over state structures. ${ }^{83}$ The Opération Vallée du Sénégal-Térékolé-Magui was never well-equipped, and, at a time of structural adjustment programs, there was little hope for the state's renewed involvement in it. ${ }^{84}$ The way GAO distanced itself from government structures during the project's conception caused friction, notably with the Minister of Transport, who was made aware of the road project long after work had started on it. ${ }^{85}$ Collaboration with the state's technical services went more smoothly, since the station relied on the expertise of their staff when designing their early broadcasts: health programs were devised in discussion with medical

\footnotetext{
${ }^{81}$ Interview with Ladji Niangané, Bamako, 17 Apr. 2018.

${ }^{82}$ Interviews with Dramane Sidibé, Lany, 13 Mar. 2019 and Dioncounda Diabira, Gakoura, 15 Mar. 2019.

${ }^{83}$ ARRK, G. Sivini, 'Les origines de la Radio Rurale de Kayes en tant qu'instrument de développement', (unpublished paper prepared for the international conference L'avenir des radios rurales en Afrique, Rende, 2427 Oct. 1991), 3.

${ }^{84}$ AGRK, Opération Vallée du Sénégal-Térékolé-Magui, 'Rapport annuel d'activité, campagne 1983/1984'.

${ }^{85}$ Interview with Ladji Niangané.
} 
teams, and broadcasts on hydraulics or cattle farming required the intervention of government-appointed technicians.

Although international return migrants constituted the backbone of the RRK's initial team, contributors from various social and geographical backgrounds were also brought in. Oumar Diagouraga, one of the station's first presenters, remembers how he was recruited while passing through town:

I am a guitarist, a singer, and the producer of the Troupe de Kayes. In 1988, I arrived in Kayes from Nioro for the Biennale [a state-organized biennial cultural and sportive contest]. When I got there, a teacher friend of mine said he'd been asked to speak about water treatment using bleach. He found it difficult, so he asked: 'Diagous, can you come to the station and help me?' When the Italians heard me speaking Soninke and Bamanan, they appreciated the way I explained things and invited me to join the team. That's how I left my job in the Nioro area where I provided literacy classes for the ODIK [Opération de développement intégré du Kaarta]. ${ }^{86}$

Diagouraga's double training as an artist and a tutor in a rural scheme provided him with valuable skills for the radio project. Unemployed graduates and teachers, coming from Kayes, Nioro, or Kéniéba also provided an important addition to a core team dominated by return migrants and village-based contributors.

\footnotetext{
${ }^{86}$ Interview with Oumar Diagouraga, Kayes, 7 Nov. 2017.
} 
Beyond their initial involvement, migrants again played a crucial role in the early 1990s due to the conjunction of internal factors (a lack of funding at the end of the project) and external dynamics (political changes in Mali). The initial radio project had been planned for two years: given the length of the technical and infrastructural preparation, it officially ended in February 1989, only six months after RRK had gone on air. From then, the situation was precarious, relying on the unpaid involvement of locally trained producers, and on recycling previously recorded broadcasts. ${ }^{87}$ Nevertheless, GAO remained involved and tried to find funds outside its own irregular contributions. Authorities were called upon at local and national level: the Gouvernorat agreed to pay the electricity bills, while the Ministry of Information paid the telephone bills. ${ }^{88}$ At first, GAO managed to negotiate short extensions of the initial agreement (three to six months), at a time when the possibility of renewed strong involvement on behalf of the Italians was still in the air. This, however, never materialized, due to a wider reorientation of Italian aid toward Eastern Europe at the expense of involvement in Sub-Saharan Africa, as well as for other internal reasons. ${ }^{89}$

As a result, in Kayes, solutions had to be perennially thought up. From September 1989, the station was run by a Comite de gestion with representatives from four local associations: the aforementioned URCAK and Diama Djigui, as well as the Organisation rurale pour le développement intégré de la Kolimbiné and the Union des tons paysans pour le développement. ${ }^{90}$ The Organisation was, like URCAK and Diama Djigui, a transnational

\footnotetext{
${ }^{87}$ Interview with Barka Fofana, Kayes, 16 Jan. 2018.

${ }^{88}$ ARRK, A. Cavazzani, 'Note pour la définition du statut de la Radio Rurale de Kayes', 19 Sept. 1990.

${ }^{89}$ When the FAI mandate expired in 1987, new legislation was put in place, but 'the actual funds committed to bilateral projects greatly exceeded the allocated budget, and in July 1989 all development aid funds were frozen. Small projects conducted by NGOs were severely affected.' Bollini and Reich, 'Italian fight', 612.

90 'Tons' were village associations that were revived under Moussa Traoré.
} 
association including returnees from France. ${ }^{91}$ The Union, on the other hand, was a local setup. The spatial areas where these four associations were active roughly mapped the surroundings of Kayes (see Fig. 1). Each one was supposed to contribute to the RRK both financially on a monthly basis and with broadcasts of their own. After six months, however, their payments became increasingly erratic, and other sources of funding were sought.

Meanwhile, the media and political landscape was changing drastically. In September and October 1991, two non-state radios opened in Bamako, even before the legal framework changed in $1992 .{ }^{92}$ The idea that the RTM would gain control over RRK, benefitting from its much better installations, lost traction as it became clear that RRK could gain legal status as an independent radio station. In September 1991, participants in a meeting held in Kayes demanded that RRK remain private and be granted a legal status in view of the 'complementary nature of the Rural Radio and the Regional Radio of Kayes' ${ }^{93}$ The need for such a public reassertion attests to the uncertainties that still prevailed. RRK soon became a founding member of the Union des radiodiffusions et télévisions libres du Mali upon the latter's creation in 1992, thus formalizing its status as a private station.

The station sought both financial and legal stabilization. To raise funds, the director reached out to a broad range of actors. From its initial commitment to themes linked to development, the station evolved to give airtime to NGOs, as well as to political and religious actors, all of which paid for their radio slots. Migrants in France were also invited to

\footnotetext{
${ }^{91}$ Daum, Les associations, ch. 9.

92 'Ordonnance du 15 janvier 1992 portant autorisation de création de services privés de radiodiffusion sonore par voie hertzienne terrestre en modulation de fréquence.' Lake, 'Mali', 23-34. After Radio Bamakan in September, Radio Liberté started broadcasting in October 1991.

${ }^{93}$ ARRK, minutes, 'Table-ronde sur la réinsertion des travailleurs migrants et le développement', 1991.
} 
contribute, and a support committee was set up with the help of the Groupe de recherche et de réalisations pour le développement rural, an NGO set up in France by former coopérants (French technical assistants posted in former colonies) and West African migrants. ${ }^{94}$ The result was the creation of the Association des radiodiffuseurs pour le développement rural de Kayes in 1992. This organization brought together, alongside the initial four associations, a wider network committed to the development of radio. It included the aforementioned Groupe, demonstrating a reorientation toward French NGOs, as well as the Centre d'échanges et de formation pratique, a resource center and NGO in Bakel with activities extending beyond Senegal toward Mauritania and Mali. ${ }^{95}$ In 1992 the RTM withdrew its last employee from RRK before launching its own regional program in September that same year. From 1992, the Association des radiodiffuseurs pour le développement rural de Kayes and GAO managed the station together, before GAO officially transferred it to the Association in 1999. ${ }^{96}$

Migrants and former migrants were key to the emergence and survival of the RRK, and the history of the radio further testifies to the importance of transnational professional exchanges and networks. Beyond migration, mobility, at different scales, has also been a key factor in the emergence of a network of radio workers and listeners. RRK gained a following

\footnotetext{
${ }^{94}$ Interview with Samba Sylla, Paris, 28 Aug. 2017. On the Groupe de recherche et de réalisations pour le développement rural, see J.-P. Dedieu, La parole immigrée: Les migrants africains dans l'espace public en France, 1960-1995 (Paris, 2012).

${ }^{95}$ Transnational links between Kayes and other localities in Senegal and Mauritania had been crucial from the outset, notably through the participation of Adrian Adams on the radio's scientific committee. An anthropologist and specialist in the Soninke language, she had been living in Kounghany, Senegal before her accidental death in 2000 .

${ }^{96}$ ARRK, letter by the Director of RRK to the Governor, 16 Aug. 1999.
} 
from large segments of the rural and urban population of Kayes by offering new channels for circulating information and new occasions for people to move around.

\section{Connections and disconnections: The radio station and changing 'infrastructures of mobility'}

Comparing radio to a road suggests that radio affects space. A simple description of a radio station is the assemblage of a fixed center emitting information and mobile transistors receiving it. However, this approach does not accurately convey the actual workings of most African FM local radio stations, which generally rely on interactions between broadcasters and the public. In RRK's case, from the outset it produced a significant increase in mobility within the area it covered.

In the first years, radio work (or 'production', to borrow the locally used phrase) involved movement: from the station in Kayes, to the villages, and back to the station; from the villages where 'producers' were trained and based to the station where they delivered their audio records to be cut to the initial 15-minute format by the technicians. Three vehicles with designated drivers were available for this work, but workers frequently had to reach their final destinations by foot, donkey cart, or pirogue. On the ground, they handed their microphones to praise-singers or elders telling sometimes conflicting versions of the same village's history; they interviewed women in charge of local development projects; they asked villagers how they coped with transport difficulties. Each field visit had to be carefully prepared. A preliminary trip without recording devices was recommended in order to get people acquainted with the project, and radio staff were warned against being monopolized 
by village authorities. ${ }^{97}$ The first radio workers used a Nagra recorder, a high-quality portable recording device which generally required the presence of a radio technician to operate. A few years later, the switch to more basic and lighter tape recorders made it possible for radio workers to record their broadcasts themselves and edit them when back in the studio. With time, and owing to the financial issues following the period of Italian cooperation, broadcasts produced in the field were increasingly replaced by studio productions. However, in presentday conversations, staff members who were present at the beginning regret this lack of field involvement: going into the villages is still thought of as central to RRK's identity.

In contrast to this travel from the radio station to the field and back, movement from rural locations to RRK's headquarters in the Plateau area of Kayes involved the listeners themselves. Hawa Bambara, one of the first workers, recalls how people would come to the station to put a face to her voice or simply to visit its facilities. ${ }^{98}$ In addition to the evident enthusiasm of rural dwellers, the interest of urban Kayesians in the station can also be gauged from listeners' letters. ${ }^{99}$ 'Before, I couldn't wait for it to be 8 pm so I could get to the cinema,' confessed one listener, 'but now I can't wait for 8:30 pm so I can switch on the radio.' A driver, as he presents himself, he goes on to describe 'Madame, who, back from the market, spends her time in the kitchen with her radio set', depicting a domestic use of radio in

\footnotetext{
${ }^{97}$ ARRK, G. Diawara, 'Programme d'animation socio-culturelle', Sept. 1988.

${ }^{98}$ Interview with Hawa Bambara, Kati, 3 July 2018.

${ }^{99}$ In September 1988, when the team launched a contest to propose a name for the radio station, hundreds of early listeners eagerly came up with a variety of names or phrases, in national languages or in French, to baptize the newcomer. For reasons unknown, no name was chosen and the station continued to be known as RRK, but the letters provide insights into the nature of the first listeners, most of whom were from Kayes, ranging from market fish-sellers to high school teachers.
} 
keeping with bourgeois models of radio presence in the family, and suggesting how radio also reworked the experience of time. ${ }^{100}$

The mobility around the station also involved letters, which the station received on a daily basis, as well as informative notices. In addition to spreading information to the public, radio technology was thus used as a means of communication between groups or individuals who knew each other, as Ibrahima Traoré, an early contributor to the radio, recalled:

Before, when there was a death or some other event, you had to send a messenger to Bamako and wait sometimes up to a week before the notice was read out on air [on national radio]. But with Radio Rurale, as soon as something happened, say you lost an animal, you could send someone, and when it was time for the daily notices slot, the event was announced. That really did a lot to familiarize the local population with the station. ${ }^{101}$

The creation of the station thus provided new ways of circulating information, in this case through the physical mobility of a person with a written letter. This channel of communication became widely used, mostly for death notices but also as a means to spread personal requests or for community leaders or officials to summon people for a meeting. Initially free, the announcements (communiqués) later became subject to a small fee - a contribution to the station budget - according to a business model which came to dominate

\footnotetext{
${ }^{100}$ ARRK, letter from Kayes N'Di, 2 Oct. 1989. On the importance of the temporal dimension of media experience, see Vokes and Pype, Chronotopes, 208.

${ }^{101}$ Interview with Ibrahima Traoré. Traoré became the first president of the Association des radiodiffuseurs pour le développement rural de Kayes.
} 
the workings of most local radio stations in Mali, whether officially associative or commercial in status.

Beyond announcements, letters by listeners generally included greetings addressed to the station staff and to the listener's family and friends, but some letters draw the attention of the radio hosts to local events or specific news. These interactions shaped strong relationships between radio hosts and their audience. Recruited as a 'radio producer' while she was working for Diama Djigui in Maréna during the early 1990s, Maly Bah went to visit numerous women's associations to record broadcasts about their successes and challenges. When she was called on to host a weekly program dedicated to women, her use of on-air callouts helped her to sustain the connections that she had made on the ground, which extended well beyond Maréna and its surroundings and contributed to her emergence as one of the station's voices. ${ }^{102}$

RRK was also part of new and often short-lived communication infrastructures and 'infrastructures of mobility', as I call them. The radio station, located in the rail station neighborhood and next to the airport, was an easy place for travelers to drop by. ${ }^{103}$ The 'fax' provides a further example of the way the station was used to monitor and enhance the mobility of persons and goods. The 'fax' or messagerie is the metonymic name given to an assemblage that included two fax machines (one in France, one in Kayes) that allowed food orders to be placed by migrants in France and delivered to their families in their villages. This complex network of exchange of goods and money across regional and transnational circuits

\footnotetext{
${ }^{102}$ Informal conversations with Maly Bah, Jan. 2019.

${ }^{103}$ Due to the city's outward expansion, Kayes-Plateau airport was closed and the new airport of Dag-Dag, outside the city, was opened in 2002.
} 
relied for a time on the radio station. ${ }^{104}$ The France-based support committee formed in 1991 suggested that the radio could help migrants' associations in Paris to transmit their orders to the cooperatives that they had started up in their villages of origin. ${ }^{105}$

As the station grew, emigrants wanted to use it: we set up a fax machine at the station and another one in Paris, in a migrant hostel [foyer]. When they wanted to deliver a message, they would send a fax, which would arrive at the station; the presenter would cut it and bring it into the studio to be broadcast. The messagerie worked well, especially in the villages organized as cooperatives: 'That load of rice, Mr. So-and-So said his parents could take it.' Or: 'I'm on my way, I'll arrive in Bamako on that day, someone should come and meet me in Bamako before heading back to Kayes. ${ }^{106}$

This station's ability to be the main news channel across the area it covered depended on its unique or dominant position. When other radio stations emerged in the 1990s, RRK's value as a source of information diminished. ${ }^{107}$

In parallel, the legal designation and political meaning of spatial divisions changed. The initial ambition of RRK in terms of coverage was formulated along the administrative divisions of the cercles of Kayes and Yélimané. Since the Kayesian transmitter, although located on a 540-meter hill, could reach the city of Yélimané but not the whole cercle, the

\footnotetext{
${ }^{104}$ Daum, Les associations, 57; P. Gonin, 'D'entre deux territoires: circulations migratoires et développement entre le bassin du fleuve Sénégal et la France' (unpublished HDR thesis, Université de Lille 1, 1997), 171-6.

${ }^{105}$ ARRK, minutes of a meeting to support RRK, Paris, Sept. 1991.

${ }^{106}$ Interview with N'Golo Coulibaly.

${ }^{107}$ The second non-state radio station in Kayes, Radio Sahel, was launched in 1997.
} 
actual range fell somewhere between 60 and $150 \mathrm{~km}$ around Kayes. In distant locations, astute listeners managed to improve reception by fiddling with technology. In October 1989 one avid listener in Yélimané instructed his friends to enhance the radio antenna with wire to improve the signal; he further suggested that RRK distribute cassettes of recorded broadcasts that faraway villagers would be willing to pay for. ${ }^{108}$

The obsession of covering the two initially selected cercles gave way to new spatial ambitions at a time when a process of decentralization was implemented in Mali, from the mid-1990s onwards. ${ }^{109}$ These dynamics touched the region of Kayes in a unique way since they intersected with the political involvement of emigrants, some of them already organized at the level of several villages, as evident from the example of Diama Djigui. ${ }^{110}$

Decentralization as a topic was heavily represented on air at RRK, which broadcast didactic forums in vernacular languages in order to accompany the process, with funding by NGO and state agencies. Leaders of the associations involved in the radio were often key actors during the municipal elections, and several were elected as mayors. The process also strongly affected the media landscape, with some FM radios emerging at the level of the municipalities (communes). However, this occurred at a moment when RRK was moving away from a reference to administrative divisions towards to other ways of delineating its audiences.

\footnotetext{
108 ARRK, letter from Yélimané, 4 Oct. 1989.

${ }^{109}$ C. Fay, Y. F. Koné, and C. Quiminal (eds.), Décentralisation et pouvoirs en Afrique: En contrepoint, modèles territoriaux français (Marseille, 2006). The names and boundaries of Kayes as a region and of its cercles were unaffected by this process; in the area, the main change was the delineation of the new subdivision of the commune.

${ }^{110}$ S. Lima, 'L'émergence d'une toponymie plurielle au Mali', L'Espace Politique, 5 (2008), https://doi.org/10.4000/espacepolitique.1115.
} 


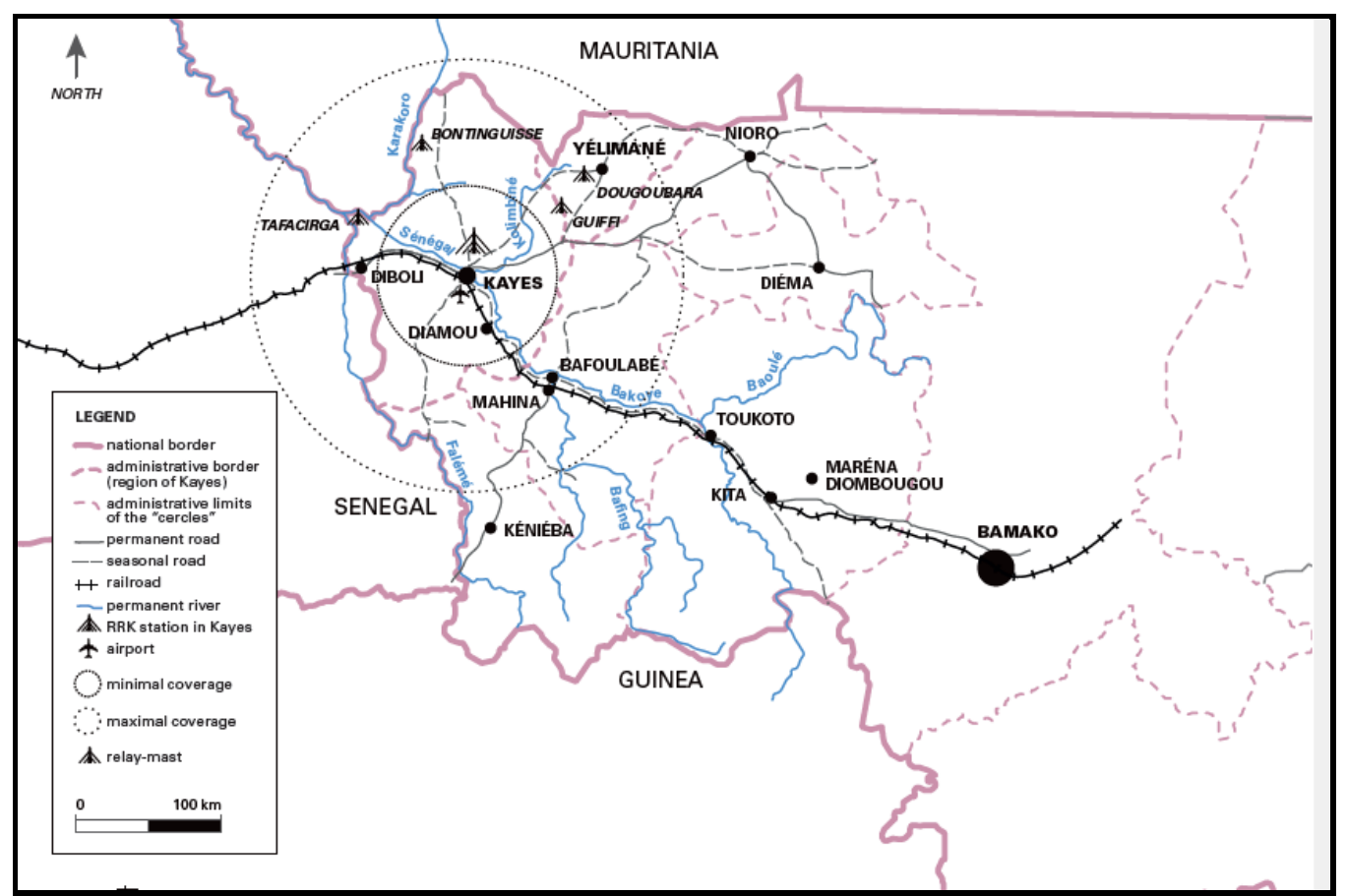

Fig. 3. Coverage in the Kayes Region ca. 1990-2000. Map by Célio Paillard.

Between 1996 and the early 2000s, RRK installed a series of relay masts that allowed it to widen its coverage (Fig. 3). Funded by the Bakel-based Centre d'échanges et de formation pratique, one of the masts was posted in Tafacirga-Gadiaga, right near Mali's western borders, from which Senegal across the Falémé River and Mauritania across the Senegal River were in easy reach (Fig. 4). Reception from Diaguily, Mauritania, in the early 2000s seems to have been available but irregular, as evident from listeners' letters asking for better maintenance of the Tafacirga relay mast. ${ }^{111}$ Though this phase of expansion was shortlived - the four relay masts were abandoned in the mid-2000s due to various maintenance problems - it corresponded to a particular involvement of the station in developing linguistic and cultural activities in the Soninke language, though the radio still broadcast in

${ }^{111}$ ARRK, letters from Diaguily, 2002 and 2005. 
several other languages. This was part of a wider revitalization movement of Soninke culture led notably by Demba Traoré. ${ }^{112}$ One decade later, with the use of phones as radio sets and the digitalization of radio, RRK regained the ability to broadcast long-distance, and even world-wide, with Soninke diasporic networks proving again vital in the expansion of its publics. Though the wider representation of all segments of Kayesian populations was still a concern of the team, the axis of community-building, where community was understood as ethnolinguistic and focused on Soninke identity, had the advantage of providing a clearer way of defining the station's character in the face of growing competition. ${ }^{113}$

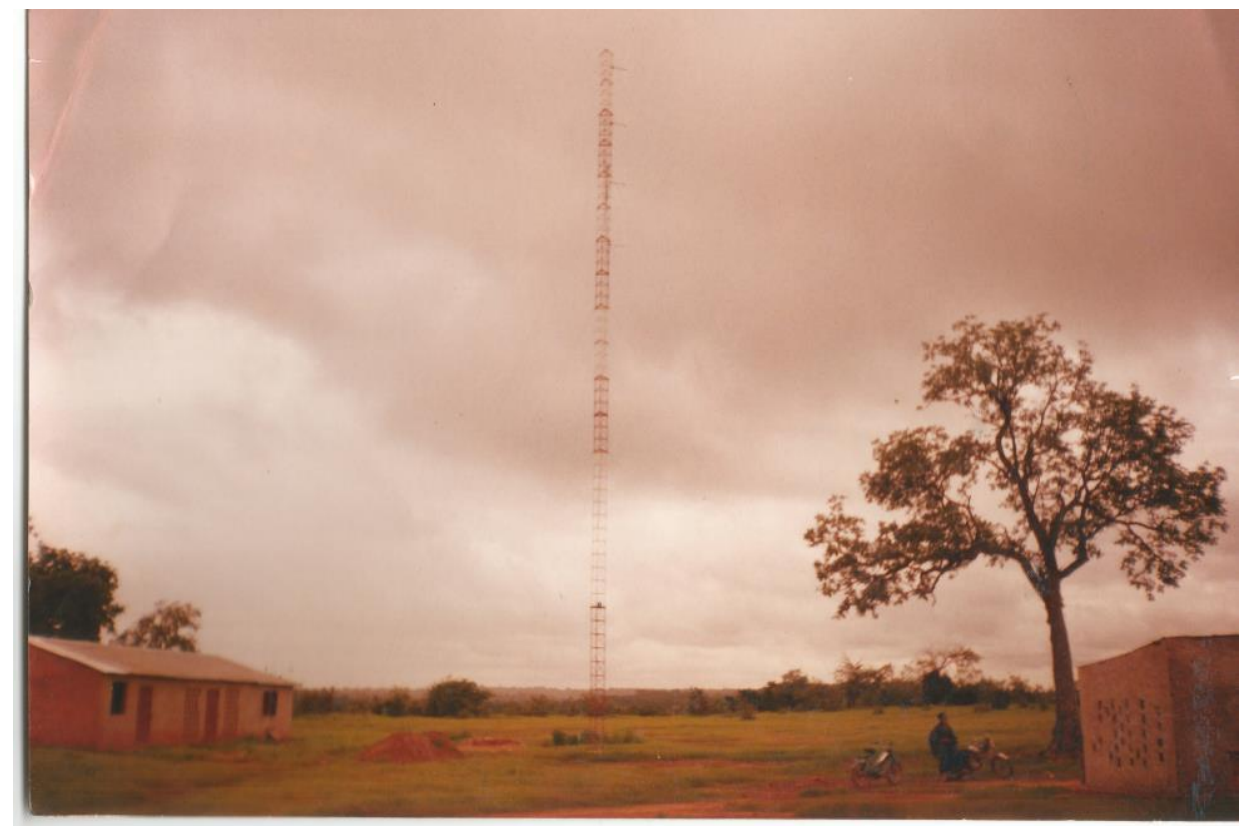

Fig. 4. A relay mast in Tafacirga, Gadiaga in the early 2000s. Photograph courtesy of Radio Rurale de Kayes.

\footnotetext{
${ }^{112} \mathrm{D}$. Traoré launched a series of broadcasts about a local philosopher, Madi-Kaama, to whom various proverbs and apologues were attributed. Research on Madi-Kaama evolved into an enterprise of Soninke revival, out of which a Soninke-language writing contest and festival emerged in 1996.

${ }^{113}$ In 2018, the Union des radiodiffusions et télévisions libres du Mali's network in the region numbered 26 recognized radio stations. Personal communication with the union's president, Bandiougou Danté, 13 Sept. 2018.
} 


\section{Conclusion}

The radio-as-a-road trope captures a perspective on radio from a region where mobility is both crucial and dependent on sociotechnical arrangements that are always being made and unmade. From this point of view, Kayes appears not in a timeless state of 'enclavement', but rather subject to forms of connection and disconnection dependent on and formative of political, infrastructural, and sociocultural changes. Linked to Burkina Faso and Senegal, Italy and France, transnational circuits of NGO actors passed on documentation, expertise, and ideas, while RRK became a model celebrated in international arenas of radio practitioners on the continent and beyond. Perhaps less visible but as decisive, key exchanges also took place between Mauritania, Senegal, and Mali via letters, festivals, and forums; within Mali through the cultural channels set up by the Malian state or under its radar; and in the villages where former migrants brought back not only transistors but also new skills and ideas on the role of the media.

The 95-kilometer dirt highway from Kayes to Diboli was inaugurated in 1990. In the absence of regular maintenance, significant renovation works had to be planned and, in 2003, the road was rebuilt and asphalted for the first time. The history of the radio station seems smoother: despite having grown out of a project with a clear timeframe, it managed to transform itself into a vibrant local institution and to survive until now. In the uncertain times of the political transition, RRK maintained itself thanks to its implementation within the return migrant-led associative sphere and its incorporation into the lives of urban and rural Kayesians - the radio seeming more solid than the road, to echo the opening quotations. These temporal disjunctions (with the radio project continuously reinterpreted and reworked 
over decades, whereas the road awaited the arrival of a completely new project) invite us to further reflect on the reasons for their initial association as one 'infrastructure program' and for the subsequent disassembling of such a view.

In the 1980s, development was key to the double project of the road and the radio station. Though no longer the product of state planning, the idea of bringing 'désenclavement' to a whole region through various infrastructural projects (road, radio) still held for the NGOs and authorities. The implementation of the project also spoke to the link between radio, in the sociotechnical form it took at this time, and the intense local mobility that supported its work. The pioneer dimension of the project and the introduction of FM technology also sustained the convergence with the road. Furthermore, there was an ambiguity as to whether RRK would become part of the state-controlled radio network. In contrast, during the following decades, the station survived as an autonomous project with a continued regional ambition (it even expanded its coverage) and a transnational public, though reduced to being just one of many other FM radio stations. The FM radio format further consolidated it as a possible channel for state and NGO communications, but no longer as a key actor in the political shaping of a region. No longer could it be equated with a road. Oblivious to the political constraints of the initial period in terms of content, radio workers' present-day recollections emphasize the association between the radio and the road in order to nostalgically conjure up a time of wider ambitions for RRK, when funding from the project enabled them to crisscross the region and when they had a sense of participating in the opening up of a new space and time.

By exploring Mali’s contemporary history of military government, political transition, and the spread of independent media, this article unsettles established chronologies which tie 
together the liberalization of airwaves and the 'democratization' moment. It also lays the groundwork for new histories of radio that bridge the specialized literature on rural radio 'experiments' and the rich scholarship on media in Africa. Approaching radio both as a type of infrastructure and within wider infrastructures of mobility, this study further invites more attention to radio's technological and spatial dimensions. Demonstrating that the spacemaking potential of the radio was short-lived, the Kayesian case calls for explorations of the varying sociotechnical, political, and cultural configurations tying together the radio and space, imagined and practiced. 